\title{
Association between parental smart phone addiction and child behavioural problems
}

\author{
Meenakshi Mitra ${ }^{1}, *$ Asish Banerjee ${ }^{2}$ \\ Sri Lanka Journal of Child Health, 2021; 50(2): 266-271
}

\begin{abstract}
Background: Smart phone devices have become a potentially addictive behaviour. Parental smart phone addiction may probably have far reaching consequences on the behaviour of children.
\end{abstract}

Objectives: To study the association between parental smart phone addiction and behavioural problems in children.

Method: The study involved 500 children aged 212 years and their parents visiting the outpatient department (new and follow up cases) of a tertiary care hospital in Durgapur after receiving institutional ethical committee clearance. "Smart phone compulsion test" was given to each parent to enquire about smart phone usage practices after taking informed consent. The parents were also asked to fill in the Paediatric Symptom Checklist17 to know about behavioural problems of their children. Each responded questionnaire was assigned a specific serial number. Data from matched sets of questionnaires as per serial number were analysed using Chi-square test. $p<0.05$ was taken as significant. Odds Ratios (OR) and Relative Risks (RR) were also computed.

Results: Smart phone addiction in parents was significantly associated with overall behavioural problems $(p<0.001)$, internalization $(p<0.001)$ and externalization $(p<0.001)$ in children. No significant association was seen with attention problems. Computed values of RR and OR were also indicative of the same.

${ }^{1}$ Assistant Professor, ${ }^{2}$ Associate Professor,
Department of Paediatrics, I Q City Medical
College and Hospital, Durgapur, West Bengal,
India
*Correspondence: asishbnrj@gmail.com

(iD https://orcid.org/0000-0002-7861-6732 (Keceived on 18 May 2020: Accepted after revision on 19 June 2020)

The authors declare that there are no conflicts of interest

Personal funding was used for the project.

Open Access Article published under the Creative Commons Attribution CC-BY (c) (i) License
Conclusions: Smart phone addiction in parents was significantly associated with behavioural problems in children.

DOI: http://dx.doi.org/10.4038/sljch.v50i2.9569

(Key words: Behavioural problems, externalization, internalization, smart phone addiction)

\section{Introduction}

An association between internet and psychological health problems in children has been documented in some studies ${ }^{1-5}$. China, India and USA are the leading users of smart phones, each having more than 100 million users ${ }^{6}$. Whilst Internet was the initial technological addiction, smart phone has become a source of potential addiction ${ }^{7,8}$. Studies suggest that smart phone overuse can lead to addictive and dependency feelings ${ }^{9,10}$, dangerous use when driving ${ }^{11,12}$, and use in prohibited areas like libraries, classrooms or public transport $\mathrm{t}^{13}$. Mobile phone overuse is also associated with more psycho-pathological symptoms, like depression and anxiety ${ }^{14}$. Mental health, healthy habits and cellphone addiction are inversely related ${ }^{15}$. Mobile phones can interfere with human relationships ${ }^{16}$.

Recently, western literature has been emphasizing on the impact of parental smart phone addiction on children. This can lead to 'little ones' feeling snubbed by the devices and consequently act out ${ }^{17}$. The more parents show addiction to smart phones, the more difficulty they have to regulate their children's use of the devices ${ }^{18}$. Various other studies reflect the ill effects of parental smart phone addiction on the wellbeing of children ${ }^{19-22}$. There are about 450 million smart phone users in India $^{23}$. Smart phones provide us with a nearly endless supply of positive and negative social stimuli. Studies have shown that positive social stimuli cause a dopamine release which is probably responsible for addiction. These responses are not very unlike cocaine addiction ${ }^{24}$. De-addiction centres for smartphones and internet will be commonplace in the near future ${ }^{25,26}$. But even with such a large number of smart phone users and their potential for addiction, studies on effect of parental smart phone addiction on children in India are scarce. With the above background, we proceeded with this study. 


\section{Objectives}

To study the association between parental smart phone addiction and behavioural problems in children.

\section{Method}

A prospective study was carried out from March 2019 to March 2020, a one year period. All children of age group 2-12 years attending the paediatric outpatient department (new and follow up cases) in a tertiary hospital were included in this study. Children with pre-existing behavioural problems (those children already attending development clinic and special education clinic in our hospital) were excluded. Informed consent was taken. "Smart phone compulsion test" was selfadministered by the parents to enquire about smart phone usage practices ${ }^{27}$. The parents were also asked to fill in Paediatric Symptom Checklist-17 (PSC-17) to know about behavioural problems of their children ${ }^{28}$. The PSC-17 consists of 17 items that are rated as "Never", "Sometimes", or "Often" present. A value of 0 is assigned to "Never", 1 to "Sometimes", and 2 to "Often". The total score is calculated by adding together the score for each of the 17 items. Items that are left blank are simply ignored (i.e. score equals 0 ). If four or more items are left blank, the questionnaire is considered invalid. The responses of PSC-17 are further subdivided into externalizing problems, internalizing problems and attention problems. Externalizing problems are problem behaviours that are directed toward the external environment. They include physical aggression, disobeying rules, cheating, stealing, and destruction of property. Internalizing behaviours are negative behaviours that are focused inward. They include fearfulness, social withdrawal, and somatic complaints. A PSC17 score of 15 or higher suggests the presence of significant behavioural or emotional problems. Both questionnaires were in English as all the parents in the study population understood the language. Each responded questionnaire was assigned a specific serial number.
Ethical issues: Ethical clearance was obtained from the Institutional Ethical Committee of I Q City Medical College and Hospital, Durgapur, West Bengal, India (NIQMC/IEC/LTR/18/02/28). Written informed consent was obtained from the parents of the participants.

Statistical analysis: The data from matched sets of questionnaires as per serial number were analysed using Chi-square test. $\mathrm{p}<0.05$ was taken as significant.

\section{Results}

Following the standard procedure, a smart phone compulsion test score of 8 or more was considered addiction for an adult. A child with a score of 5 or more in $\mathrm{I}$ is considered facing internalization problem; a score 7 or more in each $\mathrm{A}$ and $\mathrm{E}$ indicates attention and externalization problem, and an overall score of 15 or more overall behavioural problems. Out of 500 parents, $138(27.6 \%)$ were found to be addicted to their smart phones, and $14 \%$ of the children had behavioural problems. Out of 138 addicted parents, $30 \quad(21.7 \%)$ reported internalization problems faced by their children, whereas for non-addicted parents, the figure was about $7 \%$. It may be seen that addicted parents have a risk of about $22 \%$ of their children having internalization problems, whereas the risk is about $7 \%$ for non-addicted parents, the relative risk comes to 3.02. An odds ratio of 3.59 shows that addicted parents are 3.59 times more likely to have their children with internalization problem, than the non-addicted parents. Smart phone addiction in parents was significantly associated with their children facing internalization problems $(\mathrm{p}<0.001)$ [Table 1].

No significant association was seen with attention problems [Table 2], but, relative risk was more than 1 .

Association was also observed with externalization $(\mathrm{p}<0.001)$, relative risk being 3.54 [Table 3].

Table 1

Association between parental smartphone compulsion score and PSC-17 internalization score of children

\begin{tabular}{|c|c|c|c|}
\hline \multirow[t]{2}{*}{ Internalization score } & \multicolumn{3}{|c|}{ Smartphone compulsion score } \\
\hline & $\begin{array}{c}\text { High }(n=138) \\
\text { n }(\%)\end{array}$ & $\begin{array}{c}\text { Low }(n=362) \\
n(\%)\end{array}$ & $\begin{array}{c}\text { Total }(n=500) \\
n(\%)\end{array}$ \\
\hline $\operatorname{High}(n=56)$ & $30(21.74)$ & $23(07.18)$ & $56(11.20)$ \\
\hline Low $(n=444)$ & $108(78.26)$ & $336(92.82)$ & $444(88.80)$ \\
\hline $\mathrm{p}$ value for Chi-square & \multicolumn{3}{|c|}{$<0.001$} \\
\hline Odds Ratio & \multicolumn{3}{|c|}{3.59} \\
\hline \multicolumn{3}{|c|}{ Risk of child having internalization problems for addicted parents } & $21.74 \%$ \\
\hline \multicolumn{3}{|c|}{ Risk of child having internalization problems for non-addicted parents } & $07.18 \%$ \\
\hline \multicolumn{3}{|l|}{ Relative Risk $=$} & 3.02 \\
\hline
\end{tabular}


Table 2

Association between parental smartphone compulsion score and PSC-17 attention problem score in children

\begin{tabular}{|c|c|c|c|}
\hline \multirow[t]{2}{*}{ Attention problem score } & \multicolumn{3}{|c|}{ Smartphone compulsion score } \\
\hline & $\begin{array}{c}\text { High }(n=138) \\
\text { n }(\%)\end{array}$ & $\begin{array}{c}\text { Low }(n=362) \\
n(\%)\end{array}$ & $\begin{array}{c}\text { Total }(n=500) \\
n(\%)\end{array}$ \\
\hline $\operatorname{High}(n=10)$ & $04(02.90)$ & $06(01.66)$ & $10(2.00)$ \\
\hline Low $(n=490)$ & $134(97.10)$ & $356(98.34)$ & $490(98.00)$ \\
\hline $\mathrm{p}$ value for Fisher Exact Test & \multicolumn{3}{|c|}{0.474} \\
\hline Odds Ratio & \multicolumn{3}{|c|}{1.77} \\
\hline \multicolumn{3}{|c|}{ Risk of child having attention problems for addicted parents } & $2.90 \%$ \\
\hline \multicolumn{3}{|c|}{ Risk of child having attention problems for non-addicted parents } & $1.66 \%$ \\
\hline \multicolumn{3}{|l|}{ Relative Risk $=$} & 1.75 \\
\hline
\end{tabular}

Note: One cell frequency was less than 5, Chi-square test was not used. So Fisher Exact Test was used.

Table 3

Association between parental smartphone compulsion score and PSC-17 externalization score in children

\begin{tabular}{|c|c|c|c|}
\hline \multirow[t]{2}{*}{ Externalization problem score } & \multicolumn{3}{|c|}{ Smartphone compulsion score } \\
\hline & $\begin{array}{c}\text { High }(n=138) \\
\text { n }(\%)\end{array}$ & $\begin{array}{c}\text { Low }(n=362) \\
n(\%)\end{array}$ & $\begin{array}{c}\text { Total }(n=500) \\
n(\%)\end{array}$ \\
\hline $\operatorname{High}(n=50)$ & $28(20.29)$ & $22(06.08)$ & $50(10.00)$ \\
\hline Low $(n=450)$ & $110(79.71)$ & $340(93.92)$ & $450(90.00)$ \\
\hline $\mathrm{p}$ value for Chi-square & \multicolumn{3}{|c|}{$<0.001$} \\
\hline Odds Ratio & \multicolumn{3}{|c|}{3.93} \\
\hline \multicolumn{3}{|c|}{ Risk of child having externalization problems for addicted parents } & $20.29 \%$ \\
\hline \multicolumn{3}{|c|}{ Risk of child having externalization problems for non-addicted parents } & $06.08 \%$ \\
\hline \multicolumn{3}{|l|}{ Relative Risk $=$} & 3.54 \\
\hline
\end{tabular}

It may be seen that addicted parents have a risk as high as 35 percent of their children having overall behavioural problems, with a relative risk of 5.48 and a high odds ratio of 7.86. It is rather frightening that addicted parents (in comparison with non-addicted parents) are about eight times more likely to have their children with overall behavioural problems. Strong statistical association is observed between smart-phone addiction in parents and overall problems of children $(\mathrm{p}<0.001)$ [Table 4].

Table 4

Association between parental smartphone compulsion score and PSC-17 overall behavioural problem in children

\begin{tabular}{|c|c|c|c|}
\hline \multirow[t]{2}{*}{ Overall behavioural problem score } & \multicolumn{3}{|c|}{ Smartphone compulsion score } \\
\hline & $\begin{array}{c}\text { High }(n=138) \\
\text { n }(\%)\end{array}$ & $\begin{array}{c}\text { Low }(n=362) \\
n(\%)\end{array}$ & $\begin{array}{c}\text { Total }(n=500) \\
\text { n }(\%)\end{array}$ \\
\hline $\operatorname{High}(n=50)$ & $48(34.78)$ & $23(6.35)$ & $71(14.20)$ \\
\hline Low $(n=450)$ & $90(65.22)$ & $339(93.65)$ & $429(85.80)$ \\
\hline $\mathrm{p}$ value for Chi-square & \multicolumn{3}{|c|}{$<0.001$} \\
\hline Odds Ratio & \multicolumn{3}{|c|}{7.86} \\
\hline \multicolumn{3}{|c|}{ Risk of child having overall behavioural problems for addicted parents } & $34.78 \%$ \\
\hline \multicolumn{3}{|c|}{ Risk of child having overall behavioural problems for non-addicted parents } & $06.35 \%$ \\
\hline \multicolumn{3}{|l|}{ Relative Risk $=$} & 5.48 \\
\hline
\end{tabular}

\section{Discussion}

The study highlights that $27.6 \%$ of the parents in the study were addicted to their smart phones. This is more than three times higher than the smartphone addiction levels in Korean adults $(8.1 \%)^{29}$. The cheaper cost of smart phones and data plans probably leads to easier access to smartphones, while lack of awareness about the ill effects may explain higher addiction in Indian adults as compared to their Korean counterparts. Fourteen percent of the children included in the study had behavioural problems. This was lower than the $22.7 \%$ reported in a study by Gupta et al probably because of the inclusion of an older age group of 6-18 years in their study ${ }^{30}$.

Smart phone addiction in parents was significantly associated with overall behavioural problems, internalization and externalization in children. Although western literature exists about smart phones causing parental distraction in presence of their children ${ }^{22,31}$, no such Indian study is available. 
Smart phones probably prevent the parents from providing meaningful emotional support to their children which causes their children to throw tantrums or sulk, which only add to the parents' stress leading to more withdrawal with technology, and the cycle continues ${ }^{32}$.

The strength of the study is reflected by the strong association between parental smartphone addiction and behavioural problems in children in a fairly cosmopolitan population that may be reflective of the society in general. Inability to account for confounding factors such as mental health issues, familial discord, socioeconomic factors etc. for both parental smartphone addiction and behavioural problems in children is a major shortcoming of the study.

It is recommended that parents give uninterrupted attention to the children and limit the use of smartphones in their presence. Enquiry of parental smartphone use should be made a part of regular history taking for behavioural problems in children. If smart phone addiction is suspected, they should be counseled as this problem is similar to substance abuse, with repercussions not only on self but also on the children. Impact of parental smartphone addiction on children's behaviour should be discussed on medical platforms to find effective measures. Mass media should propagate the importance of this upcoming problem.

\section{Conclusions}

Smart phone addiction in parents was significantly associated with behavioural problems in children.

\section{References}

1. Ramdhonee KS. Psychological impact of Internet usage on children/adolescents; 2012. Available from:

http://www.govmu.org/portal/sites/cert/sid 2012/Psychological\%20Impact $\% 20$ of $\% 20$ Internet $\% 20$ usage $\% 20$ on $\% 20$ Children.pdf

2. Strasburger VC, Jordan AB, Donnerstein E. Children, adolescents, and the media: Health effects. Pediatric Clinics of North America 2012; 59(3):533-87. https://doi.org/10.1016/j.pcl.2012.03.025 PMid: 22643165

3. Ray M, Jat KR. Effect of electronic media on children. Indian Pediatrics 2010; 47(7): 561-8. https://doi.org/10.1007/s13312-010-01289

PMid: 20683108
4. Moreno MA, Kolb J. Social networking sites and adolescent health. Pediatric Clinics of North America 2012; 59(3):60112.

https://doi.org/10.1016/j.pcl.2012.03.023 PMid: 22643167

5. Mitra M, Rath P. Effect of internet on the psychosomatic health of adolescent school children in Rourkela - A cross-sectional study. Indian Journal of Child Health 2017; 4(3):289-93.

6. O'Dea. Smartphone users worldwide 2016-2021. Feb 28, 2020. Available at: https;//www.statista.com/statistics/330695 /number-of-smartphone-users-worldwide/. Accessed on: 31 Mar 2020.

7. Lane W, Manner C. The impact of personality traits on smartphone ownership and use. International Journal of Business and Social Science 2011; 2: 22-8.

8. Lin $\mathrm{YH}$, Lin YC, Lee YH, Lin $\mathrm{PH}$, Lin $\mathrm{SH}$, Chang LR, et al. Time distortion associated with smartphone addiction: identifying smartphone addiction via a mobile application (App). Journal of Psychiatric Research 2015; 65:139-45. https://doi.org/10.1016/j.jpsychires.2015.0 4.003

PMid: 25935253

9. Billieux J, Van der Linden M, Rochat L. The role of impulsivity in actual and problematic use of the mobile phone. Applied Cognitive Psychology 2008; 22: 1195-210.

https://doi.org/10.1002/acp.1429

10. Chóliz, M. Mobile phone addiction: A point of issue. Addiction 2010; 105: 373-4. https://doi.org/10.1111/j.13600443.2009.0 2854.x

11. Bianchi A, Phillips JG. Psychological predictors of problem mobile phone use. Cyberpsychology and Behaviour 2005; 8: 39-51.

https://doi.org/10.1089/cpb.2005.8.39

PMid: 15738692

12. White MP, Eiser JR, Harris PR. Risk perceptions of mobile phone use while driving. Risk Analysis 2004; 24(2): 32334. 
https://doi.org/10.1111/j.02724332.2004.0 0434.x

PMid: 15078303

13. Nickerson RC, Isaac H, Mak BA. Multinational study of attitudes about mobile phone use in social settings. International Journal of Mobile Communications 2008; 6: 541-63. https://doi.org/10.1504/IJMC.2008.01932 1

14. Elhai JD, Levine JC, Dvorak RD, Hall BJ. Non-social features of smartphone use are most related to depression, anxiety and problematic smartphone use. Computers in Human Behaviour 2017; 69: 75-82. https://doi.org/10.1016/j.chb.2016.12.023

15. De-Sola Gutiérrez J,

Rodríguez de Fonseca F, Rubio G. Cellphone addiction: A review. Frontiers in Psychiatry 2016; 7:175. https://doi.org/10.3389/fpsyt.2016.00175

PMid: 27822187 PMCid: PMC5076301

16. Przybylski AK, Weinstein N. Can you connect with me now? How the presence of mobile communication technology influences face-to-face conversation quality. Journal of Social and Personal Relationships 2012; 30(3): 237-46. https://doi.org/10.1177/026540751245382 7

17. Salamon M. Parents smartphone use can affect kids' behaviour. Health Day Reporter. 2017 June 2017. Available at: https://www.webmd.com/children/news/2 0170615/when-parents-focus-onsmartphones-kids-misbehaving-can-rise. Accessed on: 31st march 2020.

18. Haelle T. Parents' smartphone addiction linked to children's' overuse of the devices. Pediatric news. 2019 May 1. Available at: https://www.mdedge.com /pediatrics/article/199963/mental-health/parents-smartphone-addiction-linkedchildrens-overuse. Accessed on: 31st March 2020

19. Steiner-Adair, C. (2013). The big disconnect: Protecting childhood and family relationships in the digital age. New York, NY: Harper.
20. Handsley E, MacDougall C, Rich M. (Eds.). (2015). Children's wellbeing in the media age: Multidisciplinary perspectives from the Harvard-Australia Symposium. New South Wales, Australia: The Federation Press.

21. Turkle, S. (2015). Reclaiming conversation: The power of talk in a digital age. New York, NY: Penguin Press.

22. Radesky JS, Kistin CJ, Zuckerman B, Nitzberg K, Gross J, Kaplan-Sanoff M, et al. Patterns of mobile device use by caregivers and children during meals in fast food restaurants. Pediatrics 2014; 133(4): 843-9.

https://doi.org/10.1542/peds.2013-3703

PMid: 24616357

23. Lohchab H. overall India handset market growth to fall in 2020. Economic Times. 24 Dec 2019. Available at: https://www.google.com/amp/s/m.econom ictimes.com /tech/hardware/ overall-Indiahandset-market-growth-to-fall-in2020/amp_articleshow/72950192.cms. Accessed on: 1st April 2020.

24. Haynes T. Dopamine, Smartphones \& You: A battle for your time. Science in the News. May 1st 2018. Available at: http://sitn.hms.harvard.edu/flash/2018/dop amine-smartphones-battle-time/. Accessed on: 1st April 2020.

25. Narayanan N.Internet de-addiction centres in Delhi, Bangalore battle India's newest lifestyle disease. 15th Sep 2014.Available at: https://scroll.in/article/678235/internetde-addiction-centres-in-delhi-bangalorebattle-indias-newest-lifestyle-disease. Accessed on: 1st April 2020.

26. Jha DN. Delhi gets its first internet deaddiction centre. Times of India. 22nd Jul 2014.

https://m.timesofindia.com/city/delhi/Delh i-gets-its-first-internet-de-addictioncentre/articleshow/38824454.cms. Accessed on: 1st April 2020.

27. Greenfield D. Smart phone compulsion test. Centre for Internet and Technology Addiction.

https://www.google.com/url?sa=t\&source =web\&rct=j\&url=https://www.anselm.edu /sites/default/files/Documents/Academics/ 
Department/Nursing\%2520Cont $\% 2520$ Ed ucation/Handouts/SMARTPHONE\%2520 COMPULSION\%2520TEST.pdf\&ved $=2 \mathrm{a}$ hUKEwiAv9Sxh8foAhWac30KHf3cD6I QFjABegQIBBAB\&usg=AOvVaw1DbjL ZN3mJ5WSOHxyHJ9Lr\&cshid $=1585738$ 711905 Accessed on: $2^{\text {nd }}$ March 2019.

28. Murphy JM, Bergmann P, Chiang C, Sturner R, Howard B, Abel MR, et al. The PSC-17: Subscale scores, reliability, and factor structure in a new national sample. Pediatrics2016; 138(3):e20160038. https://doi.org/10.1542/peds.2016-0038 PMid: 27519444 PMCid: PMC5005018

29. Kim H. Exercise rehabilitation for smartphone addiction. Journal of Exercise and Rehabilitation 2013; 9(6): 500-5. https://doi.org/10.12965/jer.130080 PMid: 24409425 PMCid: PMC3884868

30. Gupta AK, Mongia M, Garg AK. A descriptive study of behavioural problems in school-going children. Industrial Psychiatry Journal 2017; 26(1):91-4. https://doi.org/10.4103/ipj.ipj_39_17 PMid: 29456329 PMCid: PMC5810175

31. McDaniel BT. Parent distraction with phones, reasons for use, and impacts on parenting and child outcomes: A review of the emerging research. Human Behavior \& Emerging Technologies 2019; 1:72-80. https://doi.org/10.1002/hbe2.139

32. PTI. Parents, take note! Smartphone usage during family time may affect your kids' behavior. Economic times. 14 ${ }^{\text {th }}$ June 2018. Available at: https://www.google.com/amp/s/ $\mathrm{m}$.economictimes.com/magazines/panache /parents-take-note-smartphone-usageduring-family-time-may-affect-your-kidsbehaviour/amp_articleshow/64588157.cm s. Accessed on: 1st April 2020. Accessed on: 1st April 2020. 